\title{
Inch Unit of Length
}

National Cancer Institute

\section{Source}

National Cancer Institute. Inch Unit of Length. NCI Thesaurus. Code C69445.

A header concept for the various measurement units based on inches. 